\title{
А.Н. Карлюкевич
}

Белорусский государственный университет,

Издательский дом «Звязда», Беларусь, г. Минск, e-mail karlykevich@yandex.by

\section{АИТЕРАТУРНЫЕ КОНТАКТЫ БЕААРУСИ И КАЗАХСТАНА: ИСТОРИЯ, СОВРЕМЕННОЕ СОСТОЯНИЕ, ОБЩЕЕ И ОСОБЕННОЕ}

Беларусь в XXI веке демонстрирует бережное и уважительное отношение к национальной литературе и культуре. Международный симпозиум китераторов «Писатель и время», который проводится сеАьмой гоА в Минске в дни работы Минской межАународной книжной выставки-ярмарки, является площаАкой Аля обмена мнениями по актуальным литературным, общецивилизационным вопросам и направлен на сохранение Ауховно-нравственных основ развития общества и государства. В литературах Беларуси и Казахстана раскрывается этнокультурная идентичность и определяется выход в мировую митературу. Постижение себя, утверждение себя - это и открытие мира.

В основе методологии статьи - филологический анализ художественного текста, в том числе переводного. Результаты Аанного исследования направлены на расширение и углубление диалога мастеров художественного слова Беларуси и Казахстана, активизацию литературного сотрудничества, выявление и пропаганду наиболее значимых в художественном плане произведений Авух стран. Этому, безусловно, способствует функционирование на базе издательского дома «Звязда» интернет-портала «Созвучие: митература и публицистика стран Содружества» (sozvuchie.zviazda.by), на котором размещаются новые материалы о национальных литературах стран СНГ. В серии «Созвучие сердец» издательского дома «Звязда» изАан сборник произведений писателей Беларуси и Казахстана «Не ведая границ», в опубликованных художественных текстах отражаются концепт памяти и современная эпоха.

Ключевые слова: постсоветское пространство, художественный перевоА, критика, альманах, митературное сотрудничество.

\author{
A.N. Karlyukevich \\ Belarus State University \\ Zvyazda Publishing House, Belarus, Minsk, \\ e-mail karlykevich@yandex.by

\section{On the historical and present special literary relations between Belarus and Kazakhstan}

Belarus in the XXI century demonstrates a careful and respectful attitude to national literature and culture. The international literary symposium «Writer and Time», which is being held for the seventh year in Minsk during the Minsk International Book Fair, is a platform for exchanging views on topical literary, general civilization issues and is aimed at preserving the spiritual and moral foundations of the development of society and the state. Ethnocultural identity is revealed in the literatures of Belarus and Kazakhstan and the way out into world literature is determined.

The methodology of the article is based on a philological analysis of a literary text in translation. The results of this study are aimed at expanding and deepening the dialogue between the masters of the artistic word of Belarus and Kazakhstan, intensifying literary cooperation, identifying and promoting the most artistically significant works of the two countries. This is undoubtedly facilitated by the functioning of the Internet portal «Consonance: Literature and Journalism of the Commonwealth Countries» (sozvuchie. zviazda.by) based on the publishing house "Zvyazda», which posts new materials about the national literatures of the CIS countries. In the series "Consonance of Hearts» by the publishing house "Zvyazda» a collection of works by Belarusian and Kazakh writers «Knowing No Bounds» has been published, the concept of memory and the modern era are reflected in the published literary texts.

Key words: post-Soviet space, literary translation, criticism, almanac, literary collaboration. 


\author{
А.Н. Карлюкевич \\ Беларусь мемлекеттік университеті, \\ «Звязда» баспа үйі, Беларусь, Минск к. \\ e-mail: karlykevich@yandex.by \\ Беларусь пен Қазақстанның әдеби байланыстары: \\ тарихы, қазіргі жағдайы, ұқсастықтары мен ерекшеліктері
}

\begin{abstract}
XXI ғасырдағы Беларусь ұлттық әдебиет пен мәдениетке мұқиятпен және құрметпен қарайды. Минск халықаралық кітап көрмесі күндері кезінде жетінші жыл өткізіліп отырған «Жазушы және уақыт» халықаралық әдеби симпозиумы - әдебиет пен жалпы өркениеттің өзекті мәселелері бойынша пікір алмасуға арналған алаң болып табылады және қоғам мен мемлекеттің дамуының рухани-адамгершілік негіздерін сақтауға бағытталады. Беларусь пен Қазақстанның әдебиеттерінде этномәдени сәйкестілік айқындалып, әлемдік әдебиетке шығудың жолы анықталады. Өзін-өзі тану, өзін-өзі растау - бұл деген әлемді ашу.

Мақаланың әдіснамасы көркем мәтінді, оның ішінде аударманы филологиялық тұрғыдан талдауға негізделген. Осы зерттеудің нәтижелері Беларусь пен Қазақстанның көркем сөз шеберлерінің диалогын кеңейтуге және тереңдетуге, әдеби ынтымақтастықты жандандыруға, екі елдің көркемдік жағынан аса маңызды болып табылатын туындыларын анықтауға және насихаттауға бағытталған. Бұған, әрине, «Звязда» баспа үйінің негізінде құрылған ТМА елдерінің ұлттық, әдебиеттері туралы жаңа материалдар салынып тұратын «Үндестік: Аостастық, елдерінің әдебиеті мен публицистикасы» деп аталатын интернет-порталы ықпал етеді (sozvuchie.zviazda.by). «Звязда» баспа үйінің «Жүректер үндестігі» сериясы бойынша Беларусь пен Қазақстан жазушыларының «Шекараға бөлмей» деген шығармалар жинағы жарық көрді, бұл жарияланған көркем мәтіндерде жады концептісі мен қазіргі дәуір бейнеленген.
\end{abstract}

Түйін сөздер: посткеңестік аумақ, көркем аударма, сын, альманах, әдеби ынтымақтастық.

\section{Введение}

Роль литературы в художественном и эстетическом образовании личности, в воспитании патриотизма, гражданской позиции, толерантности остается в центре внимания литературоведов, издателей, переводчиков, литературных критиков. Участники Международного симпозиума литераторов «Писатель и время» в Минске уделяют особое внимание проблемам книгоиздания и книжной культуры, традиций и новаторства, художественного перевода, современной переводческой «географии» и сохранению преемственности в литературе.

Основные дискуссионные темы симпозиума включали проблемы межкультурной коммуникации в контексте процесса глобализации; диалога культур и его роли в духовном обогащении человечества, литературы как формы взаимодействия культур. Важны концепты художественного перевода как межкультурной коммуникации. Велика значимость культуры как универсального консолидирующего пространства. Дискутировались основные факторы взаимопонимания и условия конструктивного межкультурного диалога. Было уделено внимание роли литературы в формировании взаимопонимания между народами; отражению национально-культурных особенностей в художественных текстах; изучению литератур- ного произведения как результата многовекового взаимодействия разных культур.

В рамках Дня белорусской письменности, история которых начинается с 1994 года, проводятся они в разных городах, исторических и культурных центрах страны, с большим успехом проходят мероприятия «Художественный текст как средство общения народов», «Созвучие. Язык и литература в контексте историкокультурного наследия», «Созвучие: литература как зеркало эпохи», посвященный 500-летию белорусского книгопечатания «Созвучие: слово Скорины в современном мире» (Полоцк, 2017) и другие. В последние годы Международный «круглый стол» сохраняет свое уникальное название «Художественная литература как путь друг к другу» (Иваново, 2018; Слоним, 2019; Белыничи, 2020). В разные годы в крупнейших литературных мероприятиях Беларуси принимали участие поэты, прозаики, литературоведы, главные редакторы литературно-художественного журнала «Простор», дипломаты, критики, переводчики, преподаватели вузов Казахстана. Это М.М. Ауэзов, В. Михайлов, К. Мынжасарова, К. Бакбергенов, К. Матыжанов, Б. Мамраев, У. Калижанов, Н. Акыш, Р. Маженкызы, Б. Канапьянов, В.Шупейкин, Д. Кунаев, С. Тахан, У. Тажкен, Л. Шашкова, С. Ананьева, А. Калиева, Р. Жуманова. 
Литературные портреты К. Бакбергенова, С. Ананьевой, Л. Шашковой включены в книгу «Слова Купалы крочыць па свеце» наряду с эссе о друзьях белорусской литературы, переводчиках, издателях Азербайджана, Армении, Литвы, Китая, России, Сербии, Таджикистана, Туркменистана, Удмуртии, Украины, Черногории и т.д. О современном литературном процессе Беларуси появились публикации во многих периодических изданиях, «вышли антологии белорусской поэзии на разных языках» (Карлюкевич, 2018: 4).

Актуальность статьи обусловлена систематизацией и обобщением накопленного материала по казахско-белорусским литературным связям новейшего времени.

Цель исследования - выявить общее и особенное в развитии литературного сотрудничества мастеров художественного слова Беларуси и Казахстана на основе сравнительно-сопоставительного анализа художественных текстов, диалога культур.

Задачи статьи: раскрыть своеобразие поэтики и стиля прозаических и поэтических текстов, проанализировать переводы произведений казахстанских писателей и поэтов на белорусский язык.

\section{Материал и методы}

Методика научного исследования основывается на компаративном подходе к изучению современного литературного процесса Беларуси и Казахстана, издательской политики двух стран. Важно определить вклад писателя в словесность. Актуальны, по мнению современного российского исследователя К. Галай, в сравнительном литературоведении «идеи А. Веселовского, В. Жирмунского, И. Неупокоевой, М. Храпченко и других» (Galay, 2020: 170).

Материалом исследования избраны публикации в сборнике «Не ведая границ. Казахстан Беларусь», на страницах первого литературного альманаха «Казахстан - Беларусь», переведенные на белорусский язык книги Н. Келимбетова, поэтический сборник Л. Шашковой.

\section{Обзор литературы}

История казахско-белорусских литературных связей уходит истоками в XIX век. На казахской земле побывали 3. Сераковский, Б. Залесский, А. Янушкевич. Б. Залесский издает в 1869 году, вернувшись на родину, большой живописный аль- бом «Жизнь казахских степей». А. Янушкевич оставил отзывы о казахском народе, этнографические зарисовки. Важно, что он встречался с отцом Абая - Кунанбаем. Об этом очерк «Свет неоткрытой звезды» Е. Стельмах (Стельмах, 2020). Оживают «живописные картины природы, созданные натуралистом. Автор восхитительно пишет о великолепном озере Алаколь, красоте Тарбагатая и величии Алатау» (Стельмах, 2020: 431).

В юбилейный год - год 175-летия со дня рождения Ж. Жабаева, чья поэзия переведена на более чем 50 языков народов мира, необходимо вспомнить, что в 1939 году «Песни и поэмы» Ж. Жабаева изданы в переводе на белорусский язык. В 1938 году по случаю 75-летия литературной деятельности Джамбула Я. Колас адресует ему поэтическое послание.

ГУЛАГ вошел в жизнь Н. Арсеньевой, С. Хурсика, В. Дудзицкого, П. Бителя, Я. Скрыгана, деятелей культуры и искусства. Обороняли и освобождали белорусскую землю известные государственные деятели Казахстана, писатели, поэты, литературоведы А. Шарипов, К. Токаев, К. Аманжолов, М. Алимбаев, Б. Наурызбаев, Ж. Мулдагалиев, С. Сеитов, Л. Скалковский. Литературовед, критик, поэт, переводчик С. Сеитов перевел на казахский язык стихотворения «Кто там идет?», «Солнцу» и «За все...» Я. Купалы. Много места в научном наследии С. Сеитова уделено творчеству Я. Купалы. О С. Сеитове опубликована статья в энциклопедическом справочнике «Янка Купала» 1986 года издания. В 2018 году в Минске издана трехтомная энциклопедия «Янка Купала», в третий том которой включена отдельная статья о С. Сеитове.

В Беларуси завершились съемки художественного фильма «Лето 1941 года» о партизанской юности А. Шарипова, в честь которого названа одна из улиц города Гродно. Министр просвещения Казахской ССР, директор Института литературы и искусства имени М.О. Ауэзова А. Шарипов в феврале 1940 года призван в армию и служил в 7-й танковой дивизии в Белостокской области Беларуси. Славная боевая юность отражена в его художественных произведениях.

В последние годы все явственнее в мировом литературном процессе возврат к литературноцентричной модели жизни. Вот уже не первый год на страницах журнала «Нёман» публикуются научные статьи литературоведов Казахстана. В центре их профессионального интереса - феномен медиума безвременья, литература как способ выживания в мире хаоса, кризис писатель- 
ского мастерства и дефицит смыслов. Автобиографичность как ведущая тенденция характерна литературам Беларуси и Казахстана. Своеобразие «автобиографического жанра во многих отношениях пограничного позволяют отделить его от смежных жанров: биографии, мемуаров, дневника. Граница между автобиографическим жанром и мемуарами редко бывает абсолютной, вернее говорить об автобиографичной или мемуарной доминанте» (Джолдасбекова, Таттимбетова, 2019: 142).

Городской текст как одна из тем современных литературоведческих исследований, «локальный текст и парадигматический феномен» (Баянбаева, 2019: 148) находится в центре внимания критиков и журналистов.

Художественная литература в Беларуси «неотьемлемая часть культуры страны, значимая часть государственного строительства суверенной Беларуси» (Карлюкевич, Ананьева, 2016: 13). Абсолютно новой для нобелевской традиции литературой стали произведения С. Алексиевич, умело соединяющей документальность и пронзительность повествования. Ключевую роль в ее творчестве, как и в произведениях казахстанских прозаиков «играет нарратор-автор» (Tattimbetova, Ananyeva, Zhaksylykov, 2016: 26).

\section{Результаты и обсуждение}

Беларусь вошла в творчество и судьбу многих известных писателей. Т. Шевченко, К. Рылеев, А. Грибоедов, А. Блок, А. Толстой, К. Паустовский, М. Хонинов, А. Вознесенский сопричастны с нашим краем. В Кобрино Брестской области осенью 1813 года служил А. Грибоедов. В деревне Столовичи под Барановичами проходил службу поэт К. Рылеев в 1815 году. Первая мировая война привела на белорусскую землю, в Полесье А. Блока и К. Паустовского, находившегося в составе санитарного поезда в окрестностях Кобрино. Среди раскатов артиллерийской канонады, пулеметной и оружейной стрельбы, крови и мытарств вырастал, формировался его огромный писательский талант. Он отступал с полевым санитарным отрядом от Люблина (Польша) до Несвижа (Беларусь).

Открывать белорусские страницы в наследии К. Паустовского можно путешествуя как с литературно-туристическим путеводителем с его «Повестью о жизни», где указаны конкретно географические названия мест и местечек: «Утром выехал в Несвиж», «Свой отряд я догнал в селе Замирье под Несвижем». Месяц К. Паустовский пролежал в госпитале в Несвиже после того, как попал под обстрел и был сильно ранен в ногу, выпал из седла. Лошадь доставила раненого поближе к своим. В Москву, к матери он ехал через Замирье.

Автор «Хождения по мукам» А. Толстой оставил записи о посещении станции Барановичи. Частым гостем у наших читателей был А. Вознесенский.

Из Невеля в Витебск в конце лета 1920 года переезжает философ Бахтин, где в сентябре читает лекции. Здесь же летом 1921 года состоялась его свадьба и завязалась дружба с Малевичем. Военная юность калмыцкого поэта, переводчика М. Хонинова связана с партизанским движением. После войны, сменив автомат на перо, поэт встречался со многими деятелями искусства нашей страны, в первую очередь с М. Танком. Так продолжался диалог культур, поскольку смысл и назначение жизни художника - это явление Слова, бессмертность которого детерминирована и его народными истоками, и народной памятью.

В 2015 году в серии «Сябрына: поэзия народов России» первой на белорусском языке издана книга стихотворений народного поэта Удмуртии В. Ар-Серги «Утренний ветер в окне». Изданы книги Р. Миннуллина, М. Карима, 3. Ханнановой, С. Гуртуева. Самое важное сейчас восстановление памяти о писателях, связанных с нашей республикой, многие из которых воевали и партизанили, освобождали синеокий край от фашистских захватчиков. Это задача литературного краеведения, которое позволяет установить белорусское происхождение и белорусские корни многих творцов.

Большое значение диалогу культур и литератур, «межкультурному и межэтническому» (Ananyeva, Mamrayev, 2019: 31) уделял Ч. Айтматов, роман которого «И дольше века длится день...» увидел свет на белорусском языке под двумя названиями «Буранный полустанок. И дольше века длится день...». Издание полиграфически великолепно оформленной книги художником А. Кашкуревичем приурочено к 90-летию со дня рождения писателя. Для Ч. Айтматова было важно увидеть мир через судьбу главного героя - фронтовика, железнодорожного рабочего.

Реалистичное изображение действительности остается важным направлением развития литературного процесса постсоветских стран. Интересно, как рассматривает историю социалистического реализма в советской литературе американский славист К. Кларк, соединяя «ли- 
тературную историю, антропологию, историю и литературную теорию» (Clark, 2000: 12). Герой произведений, написанных методом социалистического реализма, должен быть личностью независимо от избранной профессии, с богатым духовным миром. Таковы и герои художественных произведений 12-ти казахстанских и 10-ти белорусских авторов, опубликованных на страницах сборника «Не ведая границ. Казахстан - Беларусь». Напечатаны «Возвращение» А. Кекилбаева, «Камчигер» О. Бокеева, поэзия М. Макатаева, К. Мырзалиева, Н. Оразалина, Ф. Онгарсыновой, О. Сулейменова, Н. Алпамыскызы, В. Михайлова и Л. Шашковой.

В этом году О. Сулейменову - 85 лет. Провидческое поэтическое осмысление Времени как главной величины, тревожащей, волнующей человека, сделало поэта из Казахстана непререкаемым авторитетом в мире слова. Каждая из книг, каждое из произведений - это целеустремленный взгляд за горизонты. У нас, у белорусов, горизонты переводятся как «далягляды», как взгляд в даль. Такой и литературно-художественный альманах у нас есть - «Далягляды». Альманах художественного перевода.

Рожденные в результате художественного поиска слова-открытия не требуют перевода. Они близки и понятны казахам и русским, они открыты для всех людей нашей планеты Земля. Да, языковое осмысление, языковые краски для передачи тех или иных сравнений, символов, образов, конечно же, необходимы. Но внутри стержнем для разных народов и разных национальных литератур остаются великие художественные открытия О. Сулейменова. Его поэзия, публицистика, историко-литературные труды, пересекающие границы стран и континентов, надолго останутся фундаментальными остовами литературной, художественной миролюбивой и честной дипломатии.

О культурной стратегии «постромантического периода, литературном дискурсе и проблеме идентичности» размышляет современный грузинский литературовед-компаративист И. Ратиани (Ratiani, 2013: 196). В современном мировом литературоведении активен термин «травматический реализм» (Rothberg, 2020: 9).

$\mathrm{B}$ белорусской литературе тема подвига и защиты отечества - наиважнейшая. Да и улиц в разрушенном Минске, «собственно говоря, не было: засыпанные щебнем, заваленные глыбами сцементированного кирпича, с воронками от бомб, с расплавленным стеклом и скрюченным железом, они выглядели мертвыми и заброшен- ными - по ним трудно было не только проехать, но и пройти» (Сипаков, 2013: 137). «Город уже не был городом. Город был сплошным пожарищем» (Сипаков, 2013: 138).

Ритм мирной жизни незаметен «как дуновение ветра, звон солнечных лучей, шелест деревьев, оставшихся живыми» (Сипаков, 2013: 138). Но жизнь возрождалась и возвращалась. И партизанский парад «радостно прошел по освобожденной белорусской земле, по обугленному, но уже живому Минску» (Сипаков, 2013: 152).

Экзистенциальный смысл свободы «более всего отвечает задачам преодоления мирового политического и культурного кризиса» (Antonova, 2013:16). Работая над переводом книг Н. Келимбетова «Не хочу терять надежду», «Письма к сыну», «Зависть» на белорусский язык, я ощутил прикосновение к каким-то простым и в одночасье особым силам. Страницы этих повествований стали для меня родником новых жизненных ориентиров. Восхитила не только сила характера человека, который через неимоверную боль - и физическую, и душевную - прорывался к творчеству, правильному постижению мироздания. Восхитили рельефные сердечные мускулы написанного. Н. Келимбетов напомнил мне детские впечатления от книг других авторов, стремящихся восстановить добро, преподать урок справедливости. Я читал казахского исповедальника и открывал для себя необозримые горизонты влияния художественного слова на человека и его поступки.

Автор, чья жизнь прошла в борьбе с самим собой и бесконечных испытаниях, ведет свободный рассказ о высотах человеческого духа, который держится на культуре отношений, уровне образования, принципах веры и сдержанности. От серьезных разговоров писателя и публициста веет теплым ветром спокойной, разумной принципиальности, чистоты и значимости человеческого существования.

Белорусские издания книг Н. Келимбетова вызвали буквально шквал откликов в прессе. О произведениях казахстанского праведника написали журналы «Нёман», «Маладосць», «Гаспадыня», газеты «Літаратура і мастацтва» («Литература и искусство»), «Вечерний Минск», «Звязда», «Голас Радзімы» («Голос Родины»), «Настаўніцкая газета» («Учительская газета»). И это не случайно. Читатель сегодня соскучился по литературе, которая по-доброму, без лишнего назидания учит жить. Это тоже является неотъемлемой чертой художественного правдоискательства Н. Келимбетова. Я очень надеюсь, что 
у подобного рода книг - большое будущее. Они ведь являются защитниками человека от всех несправедливостей, от всех бед, от разрушительных последствий драм и трагедий. И написать, создать такие книги под силу лишь только личностям. Таким, как великого мужества писатель и ученый Н. Келимбетов.

По книге «Не хочу терять надежду» пишется пьеса. «Письма к сыну» заинтересовали белорусское радио. И, наверное, не за горами тот день, когда появится радиопостановка... Поиск жизненных сил в союзе с утверждением добра и справедливости всегда носит характер интернациональный. Не случайным кажется и то, что Н. Келимбетову свои стихотворения посвятили белорусские поэты лауреат Государственной премии Республики Беларусь М. Метлицкий, поэт Г. Авласенко, главный редактор журнала «Нёман» Ю. Алейченко, поэтесса Т. Сивец. Графический портрет Н. Келимбетова нарисовал белорусский художник азербайджанского происхождения К. Камал. Так выстраивается, обогащается белорусская художественная платформа нравственных и духовных устоев.

Думаю, что знакомство с творчеством Н. Келимбетова, общественная оценка в Беларуси его трудов, его художественного, публицистического проникновения в главные смыслы человеческого существования на Планете Земля откроют новые страницы белорусского прочтения произведений казахского прозаика, публициста, мыслителя.

О разнообразии постсоветского мира, разнообразии внутри Казахстана говорит своим студентам в США Н. Каффи, что учит их «более глубоко рассматривать разнообразие в основе их собственной культуры и жизненного опыта» (Caffee, 2020: 212).

Разнообразие литературы Казахстана и Беларуси представлено на страницах первого литературного альманаха «Казахстан - Беларусь». Его изданию предшествовала активизация литературного сотрудничества наших писательских союзов, функционирующие на портале «Созвучие: литература и публицистика стран Содружества» интернет-страницы, посвященные Абаю, М.О. Ауэзову, Н. Келимбетову. Ни пандемия, ни тысячи километров расстояния между Беларусью и Казахстаном, ни что иное не являются барьером для укрепления литературной дружбы, дружбы между народами наших стран. Близкие к белорусской литературе творческие личности У. Есдаулет, К. Матыжанов, Л. Шашкова, Б. Канапьянов, С. Ананьева, К. Бакбергенов, Ш. Сариев, В. Михайлов, Г. Жайлыбай, А. Ахетов, К. Мирзоев,
Р. Маженкызы, В. Шупейкин, Н. Акыш, Д. Кунаев, У. Тажкен, С. Тахан, Д. Куат, А. Хамраев, А. Калиева, Р. Артемьева, А. Масимов, Р. Жуманова и многие другие писатели, переводчики, литературоведы трудятся в Казахстане. Именно они генерируют самые различные инициативы, которые благоприятствуют развитию белорусско-казахских литературных, культурных, гуманитарных связей на современном этапе.

В средней школе имени М.О. Ауэзова, расположенной на улице М.О. Ауэзова в Минске, традиционно проводятся литературные форумы и презентации, продолжая традиции, заложенные классиками наших национальных литератур.

Лирическая героиня поэзии Л. Шашковой, белорусской поэтессы из Казахстана, будто ведет диалог со своим внутренним $я$ в надежде на обновление жизни, на возвращение ее изначальной сути, ее нравственных ценностей. Раздел «В слезах лицо» изданного в Минске поэтического сборника целиком посвящен родной для поэтессы белорусской теме. «В слезах лицо» - Беларусь, Отчизна глазами Л. Шашковой. И первые строки - про войною причиненную боль, начиная с цикла стихов «Песни жаворонков», памяти бабушки Федоры Гавриловны» (Шашкова, 2000: $35)$.

Создается впечатление, что Л. Шашкова живет, присутствует в Беларуси. Знает изнутри белорусские боли: страдающая, поруганная душа земли нашей близка и понятна автору «Диалогов с надеждой». Как яркий пример - стихотворение «Ванька-Бусел» (так и по-русски: не аист, а именно «Ванька-Бусел»). Живет в деревне дядька с необычной для чужого человека кличкой. К ней все привыкли. И слегка подшучивают над пастухом «Ванькой-Буслом», что пылит босиком за стадом. Шутка, детская дразнилка, как раз про дядьку: «Бусел, бусел, длинноносый, продал боты, а сам босый».

Деревенские старики знают: в войну сгорела вместе с женой и детьми его хата. Партизан Ванька не успел спасти семью, выскочил из лесу, а хата на глазах догорает. Вот и поседел в одночасье. Потерялся, спрятался в самом себе. И никто не может вернуть к жизни его, Ваньку-Бусла.

Многие стихи белорусского раздела книги о природе. В белорусском разделе книги и поэма «На кутью» (из Янки Купалы). Примечательно, что Л. Шашкову отличает тяготение к вершинам белорусского поэтического древа. «На кутью» это не просто перевод, а новое современное прочтение, осмысление классического, далекого от нас по времени произведения. 
Поэма «Рогнеда» создавалась в Казахстане, в Минске и Заславле. А завершала ее автор в Алматы. «Рогнеда» - проникновение в судьбу Гориславы. В «Рогнеде» слышится дыхание современности. Как завет, как надежда звучат последние строки поэмы:

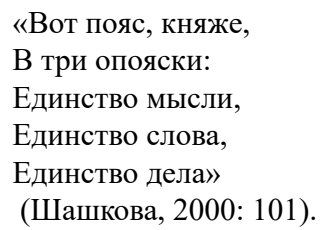

Общие темы, концепты, идеи в национальных литературах каждый писатель и поэт раскрывает по-своему. Но в литературах Беларуси и Казахстана, помимо особенного (постмодернизм и постпостмодернизм, новаторски смелая поэзия, практическое отсутствие бульварной литературы), есть, безусловно, и общее: традиции героико-патриотической литературы, детской литературы и художественный перевод, школа которого возрождается благодаря новым проектам и личным инициативам.

\section{Заключение}

Белорусско-казахское литературное и издательское сотрудничество в первые двадцать лет XXI века достигло хорошей динамики. Поэзия Абая Кунанбаева зазвучала на белорусском языке в переводах лауреата Государственной премии Республики Беларусь М. Метлицкого. За переводы Абая, опубликованные в сборнике «Степной простор», М. Метлицкий удостоен Международной литературной премии Алаш. В Минском Доме литераторов прошел вечер О. Сулейменова. Стихотворение «Олжас Сулейменов в Минске» посвятил казахскому поэту М. Метлицкий:

Стихи Олжас читает - Землю в ранах

Тепло качает на своих руках.

Литература всегда была и остается попрежнему составной связующей частью, мостом в налаживании и укреплении исторических, культурных связей. Мы восстанавливаем общее просветительское, культурное, художественное и издательское пространство. Жизнь писателя состоит из многих составляющих, на нее влияют разные факторы. Осмысливая сделанное каждым художником слова, важно учитывать атмосферу, среду, то пространство, что связано с творческой работой.

На страницах литературных журналов «Полымя», «Нёман», «Беларуская думка», на портале «Созвучие: литература и публицистика стран Содружества» активно публикуются литературоведы, преподаватели и докторанты вузов Казахстана. Новые переводы художественных произведений У. Есдаулета, С. Сеитова, Е. Раушанова, Н. Черновой, В. Михайлова, Г. Жайлыбая, Б. Каирбекова, Б. Канапьянова, Р. Маженкызы, Л. Шашковой, Н. Акыша, А. Елгезека, С. Комова и других изданы в Минске. Активно переводится белорусская литература на казахский язык, переводы сказок Л. Рублевской, А. Карлюкевича, Е. Стельмах опубликованы в журналах «Ақ желкен», «Мөлдір бұлак» и др. На казахском языке в альманахе «Казахстан - Беларусь» представлены стихотворения Н. Гальперовича, А. Бадака, М. Кобец, Т. Сивец, Ю. Алейченко. Опубликованы новые произведения на страницах журналов «Жулдыз», «Простор», альманаха «Литературная Алма-Ата», газеты «Қазақ әдебиеті». Научные статьи литературоведов Беларуси печатаются в журналах «Керуен», «Простор», в сборниках материалов Международных научных конференций в ведущих вузах Казахстана.

Международный «круглый стол» в онлайн формате «Художественная литература как путь друг к другу. Слово созидательное и слово разрушительное» в рамках Дня белорусской письменности в сентябре 2020 года Белыничах собрал 60 участников из разных стран мира. В центре внимания каждого мероприятия в Беларуси - воспитание патриотизма. Художественное слово, безусловно, созидательно.

Межлитературные связи Беларуси и Казахстана - яркий пример для стран Содружества и зарубежья.

\section{Литература}

Карлюкевіч А. Слова Купалы крочыць па свеце. - Мінск: Паліграфкамбінат імя Я. Коласа, 2018. - 175 с.

Galay K. About discussions around comparative literature // Culture in a global world. - Almaty: Print Express, 2020. - P.169174

Стельмах Е. Свет неоткрытой звезды // Казахстан в моей судьбе / Отв. редактор С. Ананьева. Т. II. - Алматы: Print Express, 2020. - C. 427-432. 
Джолдасбекова Б., Таттимбетова К. О тенденциях автобиографической прозы Ивана Щеголихина // Нёман. - 2019. №9. - С.141-145.

Баянбаева Ж. Алма-атинский текст произведений Юрия Домбровского // Нёман. - 2019. - №9. - С.145-148.

Карлюкевич А., Ананьева С. Литература Беларуси // Мировой литературный процесс XXI века. - Алматы: Әдебиет Әлемі, 2016. - С.8-40.

Tattimbetova K., Ananyeva S., Zhaksylykov A. The author's self-reflection in narratology of I.P. Shegolikhin. Journal of Language and Literature (Scopus). - 2016. - Vol. 7, 3, 26-32

Ananyeva S., Mamrayev B. The phenomenon of national cultures and literatures // Chingiz Aitmatov. Universal topics. - London: Aitmatov Academy, 2019. - P.31-36.

Clark K. The Soviet Novel: History as Ritual. - Bloomington: Indiana University Press, 2000. - 320 p.

Ratiani I. «Weltliteratur» and Émigré Writers // Literature in Exile. Emigrants' Fiction ( $20^{\text {th }}$ century experience). Volume I. VII International Symposium Contemporary Issues of Literary Criticism. - Tbilisi: Institute of Literature Press, 2013. - P.194-199

Сипаков Я. Партизанский парад // Не ведая границ / Сост. А. Бадак. - Минск: Издательский дом «Звязда», 2013. - С.137153.

Rothberg M. (2000) Traumatic Realism: The Demands of Holocaust Representation. - Minneapolis: University of Minnesota Press $-200 \mathrm{p}$

Caffee N. Kazakh culture and literature in the American higher education curriculum // Culture in a global world. - Almaty: Print Express, 2020. - P.211-217.

Antonova L. N. Berdiaev. Existentential Meaning of Freedom Literature in Exile. Emigrants' Fiction (20 $0^{\text {th }}$ century experience). Volume I. VII International Symposium Contemporary Issues of Literary Criticism. - Tbilisi: Institute of Literature Press, 2013. P.15-20.

Шашкова Л. «И вековечный только край...». - Минск: Полымя, 2000. - 110 с.

\section{References}

Ananyeva S., Mamrayev B. (2019) The phenomenon of national cultures and literatures Chingiz Aitmatov. Universal topics. London: Aitmatov Academy. - P.31-36

Antonova L. N. (2013) Berdiaev. Existentential Meaning of Freedom Literature in Exile. Emigrants' Fiction $\left(20^{\text {th }}\right.$ century experience). Volume I. VII International Symposium Contemporary Issues of Literary Criticism. - Tbilisi: Institute of Literature Press. - P.15-20.

Bayanbaeva Zh. (2019) Alma-atinskiy tekst proizvedeniy Yuriya Dombrovskogo [The Alma-Ata text of the works of Yuri Dombrovsky] Nyoman. №9 pp.145-148. (In Russian)

Caffee N (2020) Kazakh culture and literature in the American higher education curriculum // Culture in a global world. - Almaty: Print Express,. - P.211-217.

Clark K. (2000) The Soviet Novel: History as Ritual. - Bloomington: Indiana University Press. - 320 p.

Dzholdasbekova B., Tattimbetova K. O tendencijah avtobiograficheskoj prozy Ivana Shhegolihina // Njoman. - 2019. - №9. P.141-145. (In Russian)

Galay K. (2020) About discussions around comparative literature Culture in a global world Almaty: Print Express - P.169-174

Karlyukevich A., Ananyeva S. (2016) Literatura Belarusi Mirovoj literaturnyj process XXI veka [Literature of Belarus World literary process of the XXI century] Almaty: Adebiet Alemi P.8-40. (In Russian)

Karlyukevich A. (2018) Slova Kupaly krochyc' pa svece [Kupala's word walks the world] Minsk: Paligrafkambinat imya Ya. Kolasa, 175 p. (In Belorussian)

Ratiani I. (2013) «Weltliteratur» and Émigré Writers Literature in Exile. Emigrants’ Fiction (20 th century experience). Volume I. VII International Symposium Contemporary Issues of Literary Criticism. - Tbilisi: Institute of Literature Press P.194 - 199.

Rothberg M. (2000) Traumatic Realism: The Demands of Holocaust Representation. - Minneapolis: University of Minnesota Press $-200 \mathrm{p}$.

Shashkova L. (2000) «I vekovechnyj tol'ko kray...» [«And only an eternal land ...»] Minsk: Polymya 110 p. (In Russian) Sipakov Ja. (2013) Partizanskiy parad Ne vedaya granic Sost. A. Badak. [Partisan parade Knowing no borders Comp. A. Badak.] Minsk: Izdatel'skij dom «Zvyazda» P.137-153. (In Russian)

Stel'mah E. (2020) Svet neotkrytoj zvezdy Kazahstan v moej sud'be Otv. redaktor S. Ananyeva. [Light of an undiscovered star Kazakhstan in my destiny Editor S. Ananyeva.] T. II. - Almaty: Print Express. - P. 427-432. (In Russian)

Tattimbetova K., Ananyeva S., Zhaksylykov A. (2016) The author's self-reflection in narratology of I.P. Shegolikhin. Journal of Language and Literature (Scopus) Vol. 7, 3, 26-32 